\title{
The Value of Direct Instruction for At-Risk Students
}

\author{
Kevin Butler ${ }^{1}$ \\ ${ }^{1}$ Illinois Wesleyan University, Bloomington, Illinois, United States \\ Correspondence: Kevin Butler, Illinois Wesleyan University, Bloomington, Illinois, United States. E-mail: \\ kbutler1@iwu.edu.
}

Received: June 5, 2019

Accepted: May 8, 2020

Online Published: May 15, 2020

doi:10.20849/jed.v4i2.741

URL: https://doi.org/10.20849/jed.v4i2.741

\begin{abstract}
Students of color and low-income students are at a much higher risk of dropping out of school than more privileged students. Dropping out of school can lead to severe social issues -- students who drop out of school are much more likely to end up incarcerated and to remain unemployed for long periods of time. However, strong empirical research indicates that certain teaching methods are highly beneficial for the academic achievement of at-risk students in addition to being beneficial for the achievement of all students in general. These teaching methods are based around direct, teacher-centered instruction. In contrast, teaching methods based around minimally-guided instruction tend to be ineffective (or even detrimental) for at-risk students. This text outlines the benefits of direct instruction and the potential risks of minimally-guided instruction, along with specific steps for implementing effective teaching strategies.
\end{abstract}

Keywords: direct instruction, teacher-centered instruction, at-risk students, minimally-guided instruction

\section{Introduction}

It is well-established that there is a significant achievement gap in the United States between students of color and white students, and between high-income students and low-income students; this gap has persisted for decades (Coleman, 1966; Kim \& Axelrod, 2005; NCES, 2009; NCES, 2015). Due to this gap, low-income students and students of color are more likely to experience significant issues in life; specifically, "elementary and high school academic achievement scores have been shown to correlate strongly with high school completion, college enrollment, and labor market outcomes" (Kim \& Axelrod, 2005). Students who drop out of high school are considerably more likely to end up unemployed or incarcerated, and these consequences are especially prevalent among students of color (Sum, Khatiwada, \& McLaughlin, 2009). Accordingly, it is vital to implement educational practices that close the achievement gap; doing so would help prevent these at-risk students from struggling later in life. These practices can start in the classroom -- the actions of a student's teachers are one of the most important factors in a student's academic achievement (Muijs et al., 2014). There are, in fact, certain teaching strategies that have been shown to be especially helpful for the achievement of low-income students and students of color (Adams \& Engelmann, 1996; Barbash, 2012; Becker, 1977; Brophy, 1982; Brophy \& Good, 1986; Chall, 2000; Gage, 1978). These teaching strategies are based around direct instruction -- a way of organizing the classroom such that the teacher actively directs lessons and has substantial interaction with the students. However, there is an issue; professors of education -- those who train the teachers of the United States -- overwhelmingly disparage direct instruction. They show, instead, strong support for constructivist teaching methods (Carnine, 2000; Farkas \& Duffett, 2010; Krahenbuhl, 2016; Stone, 1996; Stone, 2002). These methods include "discovery-based learning," "inquiry-based learning," and "child-centered learning." Although the terms are distinct, the education literature clearly indicates that they are virtually identical pedagogical approaches (Clark, Kirschner, \& Sweller, 2006). While such methods may sound intuitively appealing, they are likely more harmful than helpful, especially for disadvantaged students. The first section of this text will review key findings from the research literature on effective instruction and provide recommendations for teachers. The second section of this text will review the literature regarding constructivist teaching methods and explain why they should be avoided in the classroom in many circumstances.

\subsection{Direct Instruction: A Brief Explanation}

As explained by professor Jeanne Chall in her book The Academic Achievement Challenge, "the findings [of the research literature on teaching] are quite consistent" (Chall, 2000). Chall explains in detail that direct, 
teacher-centered instruction is considerably more effective than student-centered or minimally-guided instruction for students' academic achievement (Chall, 2000). What does direct, teacher-centered instruction consist of? In an extensive literature review, Jere Brophy and Thomas Good provide the following general description of "active teaching," based on the research findings that direct instruction is highly effective for promoting academic achievement:

Students achieve more in classes where they spend most of their time being taught or supervised by their teachers rather than working on their own (or not working at all). These classes include frequent lessons...in which the teacher presents information and develops concepts through lecture and demonstration, elaborates this information in the feedback given following responses to recitation or discussion questions, prepares the students for follow-up seatwork activities by giving instructions and going through practice examples, monitors progress on assignments after releasing the students to work independently, and follows up with appropriate feedback and reteaching when necessary. The teacher carries the content to the students personally rather than depending on the curriculum materials to do so, but conveys information mostly in brief presentations followed by recitation or application opportunities. (Brophy \& Good, 1986)

As previously mentioned, this form of teaching is especially effective for low-income students and students of color, who are most at risk of falling behind academically. A literature review by Rosenshine and Stevens (1986) breaks down this form of instruction into various "teaching functions":

1. Begin a lesson with a short review of previous, prerequisite learning.

2. Begin a lesson with a short statement of goals.

3. Present new material in small steps, with student practice after each step.

4. Give clear and detailed instruction and explanations.

5. Provide a high level of active practice for all students.

6. Ask a large number of questions, check for student understanding, and obtain responses from all students.

7. Guide students during initial practice

8. Provide systematic feedback and corrections.

9. Provide explicit instruction and practice for seatwork exercises and, where necessary, monitor students during seatwork.

In order for teachers to implement these functions, it is helpful to have clearly defined, concrete steps. Ellis and Worthington (1994) describe eight "enabling skills" that involve precisely such steps; their explanation can be applied practically by teachers. The skills are gaining students' attention, goal setting/communicating lesson goals, teacher motivation/enthusiasm, lesson entry, demonstration/modeling, rehearsal of skill, practice, and lesson closure (Ellis \& Worthington, 1994).

\section{Concrete Steps and Recommendations From Ellis's and Worthington's Enabling Skills}

\subsection{Gaining Students' Attention}

For gaining students' attention, Ellis and Worthington recommend using signals, having a proper seating arrangement, and reducing stimulus complexity. Signals can include a particular phrase or hand motion that indicates that students should pay attention or that the lesson is about to begin. Seating arrangements should ideally consist of either a semi-circle (for small groups of students), rows, or a horseshoe arrangement; in all of these cases, all students should be facing the teacher. "Stimulus complexity" refers to how information is presented. One can only hold a few "bits" of information in his working memory at a time, and ensuring that students' working memory is not "overloaded" is helpful for their learning (Sweller, van Merrienboer, \& Paas, 1998). Effective ways of preventing "overload" include explaining material in small steps, eliminating unnecessary language from one's explanations, and using visual aids (such as graphic organizers and outlines).

\subsection{Setting and Communicating Goals}

With regards to setting and communicating goals, it is important that a teacher has clear objectives for each lesson and that he communicates those objectives to the students; this has been linked strongly with student achievement (Berliner, 1988). Additionally, providing a structure -- outlining, essentially, how students will achieve the objectives -- is helpful for their learning (Brophy \& Good, 1986).

\subsection{Teacher Enthusiasm}

Teacher enthusiasm is a consistent predictor of student achievement (Brophy \& Good, 2008; Patrick, Hisley, \& 
Kempler, 2000; Rosenshine, 1970). Furthermore, with regards to teacher motivation, teachers who see themselves as responsible for their students' learning and do not expect students to learn primarily on their own are more effective (Brophy \& Good, 1986). Accordingly, it is important to try to maintain a high-energy classroom atmosphere and consider oneself the primary factor in a student's learning.

\subsection{Lesson Entry}

According to Ellis and Worthington (1994), "[t]he first few minutes of the class period are the most crucial time in terms of teacher impact." If one does not capture students' interest at the beginning of class, then the lesson will likely not be as successful. Ellis and Worthington recommend making comments that appeal to students' interests and personal backgrounds; they also recommend using a "shock" factor, such as beginning class with an unusual, yet thought-provoking question. Additionally, during the lesson entry, the teacher should explain what activities will occur in the lesson and what their purpose is; orienting students toward the content of the lesson this way increases achievement (Brophy \& Good, 1986).

\subsection{Demonstrating/Modelling}

This is when the teacher actively shows students how to perform a skill or utilize knowledge. Rosenshine and Stevens (1986) state that effective presentation of material requires avoiding ambiguous language, focusing on one point at a time, giving step-by-step instructions as necessary, giving redundant explanations if required, and giving specific and concrete examples.

\subsection{Rehearsal}

Rehearsal requires substantive interaction between the students and teacher. Students need the opportunity to rehearse acquired knowledge with the teacher. One of the best ways to do this is to ask questions very frequently during class (Brophy \& Good, 1986; Rosenshine, 2002; Rosenshine \& Stevens, 1986). It is best to present a small amount of material and then ask many questions about it before presenting the next section of material; this helps students learn the material because they can immediately practice recalling and rephrasing what the teacher has taught.

\subsection{Practice}

Practice essentially extends the sixth enabling skill; the rehearsal in which students engage when they are responding to the teacher's questions is a form of guided practice -- the teacher is having the students apply what they have learned, but still with strong guidance and immediate feedback. Following guided practice, a teacher should give students time for independent practice. This may consist of independent seatwork or small-group work. This gives students the opportunity to practice applying acquired knowledge to a level of fluency. It is important, however, to ensure that students are prepared for independent practice -- they should have a high level of success when doing independent work (Brophy \& Good, 1986; Rosenshine \& Stevens, 1986). If many students are struggling, reteaching is necessary.

\subsection{Lesson Closure}

The end of a lesson is important primarily for summarizing and reviewing what students have learned. The objectives of the lesson should be reiterated, and the material covered should be briefly summarized so that students can see how the activities of the lesson led to the students achieving the objectives.

\section{Summary of Direct Instruction and Its Implications for Teaching}

Direct, teacher-centered instruction is highly effective for increasing student achievement, and this is especially true for at-risk students. Raising the achievement of at-risk students is vital for preventing them from facing severe consequences later in life. In order to help these students, it is recommended to employ the "enabling skills" outlined by Ellis and Worthington. When put together, these skills lead to a strategy that has been called by various names; Stevens and Rosenshine (1981) refer to it quite clearly as "demonstrate--prompt--practice." Ultimately, the teacher should take as much responsibility as possible for students' learning, and therefore, he should actively present material, guide students through it, and give them necessary time for supervised, independent practice.

\section{Minimally-Guided Instruction: A Popular, But Potentially Harmful, Alternative}

As mentioned towards the beginning of this text, most professors of education in the United States disparage direct instruction and instead support constructivist teaching methods (Carnine, 2000; Farkas \& Duffett, 2010; Krahenbuhl, 2016; Stone, 1996; Stone, 2002). Constructivist teaching methods include "discovery-based learning," "inquiry-based learning," "project-based learning," and similar approaches that can be labelled as "minimally-guided instruction" (Clark, Kirschner, \& Sweller, 2006). The general idea behind these teaching methods is that the teacher should serve as a "guide on the side" rather than a "sage on the stage"; direct 
presentation of material is to be kept to a minimum. Instead, students should be placed in an information-rich environment in which they should discover key ideas themselves and construct knowledge by cooperating with each other. Advocates of minimally-guided instruction argue that it promotes critical-thinking skills as opposed to direct instruction's supposed focus solely on "facts" (Daniels, Hyde, \& Zemelman, 2005; Hirsch, 1996). However, the research literature supporting minimally-guided instruction is essentially non-existent (Adams \& Engelmann, 1996; Brophy \& Good, 2008; Clark, Kirschner, \& Sweller, 2006; Kozloff, LaNunziata, Cowardin, \& Bessellieu, 2001). Most literature in support of minimally-guided instruction consists solely of anecdotes, statements of rationale, and very small-scale, subjective case studies (Brophy \& Good, 2008). While such literature is not useless, it is only the first step in determining which teaching strategies are effective. Ellis and Fouts (1993) outline three levels of educational research. Level one consists of theories/hypotheses developed from anecdotes and case studies; level two consists of empirical research done on a small scale (for example, a comparison between two classrooms where a specific teaching method is employed in only one of those classrooms); level three research is empirical research on a much larger scale (such as throughout an entire school or district). For minimally-guided instruction, there is only support from level one research, whereas for direct instruction, there is significant support from level three research. Therefore, implementing minimally-guided instruction is, at the very least, risky.

Perhaps even more troubling is that in addition to being ineffective for the achievement of all students in general, minimally-guided instruction tends to widen the achievement gap between privileged students and at-risk students (Clark, Kirschner, \& Sweller, 2012). Hertzberg (1981, cited in Brophy, 1990) said regarding discovery-based programs for teaching social studies that such programs "emphasized the brightest students without much consideration of other students." Lisa Delpit describes her perception of this problem via her own experience; working at an inner-city school in which the majority of students were African American, she found herself teaching quite differently from the other African American teachers at the school. While she taught using the minimally-guided instruction methods advocated by her college professors, the other African American educators used more "traditional" strategies. The result was that Delpit saw a gap between her students:

I was an exception to the other black teachers. I socialized with the young white teachers and planned shared classroom experiences with them. I also taught as they did. Many people told me I was a good teacher: I had an open classroom; I had learning stations...I threw out all the desks and added carpeted open learning areas. I was doing what I had learned -- and it worked. Well, at least it worked for some of the children. My white students zoomed ahead. They worked hard at the learning stations. They did amazing things with books and writing. My black students played the games....and they threw the books around the learning stations...Some of them even learned how to read, but none of them as quickly as my white students. I was doing the same thing for all my kids -- what was the problem? (Delpit, 1986).

As Delpit continued teaching, she gradually transitioned to more traditional methods and saw the gap between her students close (Delpit, 1986). Although this is just one teacher's observations, they are backed up by the research literature -- direct instruction is especially helpful for students of color and low-income students, and minimally-guided instruction tends to widen the achievement gap (Adams \& Engelmann, 1996; Barbash, 2012; Becker, 1977; Chall, 2000; Clark, Kirschner, \& Sweller, 2012; Gage, 1978; Kozloff et al., 2001).

It is worth asking if there is ever an appropriate time to implement minimally-guided instruction. Clark, Kirschner, and Sweller (2006) note that once a person has a significant quantity of background knowledge in a subject, minimally-guided instruction may be useful as a way for the person to apply his knowledge; for example, if students have been taught in detail the steps for writing a good essay, it could be valuable to allow them to write an essay about whatever topic they would like. This allows them to explore and discover new ideas; however, they are discovering these ideas by implementing knowledge (the steps for writing an essay) that has been taught directly. In other words, knowledge that is a part of the curriculum has been taught explicitly; students are not expected to discover it on their own. Rather, they have the opportunity to apply acquired knowledge in order to discover information that interests them. This saves students from the "falling behind" that is caused by being expected to "discover" knowledge that is required for their classes.

Additionally, although constructivism as an "overall" approach to teaching is generally ineffective, there are certain aspects of teaching advocated by supporters of constructivism that show significant promise, and these aspects are often ignored in the literature of supporters of direct instruction. One such element is known as "culturally relevant/responsive pedagogy." Often described hand-in-hand with constructivism (as it is a learner-centered viewpoint), culturally relevant pedagogy involves examining one's views towards diverse learners, learning in-depth about one's students and their families, and incorporating students' interests and cultural backgrounds into instruction (Gay, 2002; Richards, Brown, \& Forde, 2007). There are at least three potential benefits to including culturally relevant pedagogy into one's teaching. Firstly, one's prior knowledge 
greatly impacts how easily one can learn new information (Willingham, 2009). Accordingly, taking into account students' personal interests and cultural histories can help a teacher develop a curriculum and instructional format that "reaches" students both personally and intellectually and improves their learning. Secondly, a positive classroom atmosphere has been shown to improve students' academic achievement (Brophy \& Good, 1986). Including students' personal interests and backgrounds could help students feel more "welcome" in the classroom, thus leading to a more pleasant, cooperative environment that is beneficial to both student and teacher. Thirdly, a teacher's expectations of his students can influence students' academic achievement (O'Neill, 1988). Therefore, the part of culturally relevant pedagogy that consists of examining one's own views towards diverse learners can be beneficial - if a teacher has unrecognized biases against certain groups of students, reflection can help the teacher realize this and adjust their expectations, ensuring that they respect and hold all students to high standards.

Considering all of the above information, it is advisable to avoid using constructivism as one's primary method for teaching. However, implementing certain aspects of it - specifically, culturally relevant pedagogy can be quite helpful for students. Likely direct instruction of a well-organized curriculum informed and "tweaked" according to students' personal interests and cultural backgrounds could be a highly effective way to incorporate that beneficial element of constructivism into a more direct teaching approach.

\section{Conclusion}

Students of color and low-income students have a considerable risk of facing serious issues in their lives if they do not achieve well in school. In order for teachers to support these students, they should focus on implementing direct, teacher-centered instruction. Minimally-guided instruction (including "discovery-based learning" and "inquiry-based learning") should be implemented with extreme caution, ideally with a back-up plan based around more direct instruction. In fact, minimally-guided instruction should generally only be considered for students who already have considerable background knowledge in the subject in question. In order to prevent social and behavioral issues, it is best for most students to be taught via direct instruction. That being said, the element of culturally responsive pedagogy that is frequently embraced by constructivist advocates, yet ignored by advocates of direct instruction, is worth implementing in the classroom due to its benefits to students' academic achievement and well-being.

\section{References}

Adams, G., \& Engelmann, S. (1996). Research on direct instruction: 25 years beyond DISTAR. Seattle, WA: Educational Achievement Systems.

Barbash, S. (2012). Clear teaching: With direct instruction, Siegfried Engelmann discovered a better way of teaching. Education Consumers Foundation.

Becker, W. (1977). Teaching reading and language to the disadvantaged: What we have learned from field research. Harvard Educational Review, 47(4), 518-543. https://doi.org/10.17763/haer.47.4.51431w6022u51015

Berliner, D. (1988). The half-full glass: A review of research on teaching. In E. Meyen, G. Vergason, \& R. Whelan (Eds.), Effective instructional strategies for exceptional children. Denver, CO: Love Publishing.

Brophy, J. (1982). Successful teaching strategies for the inner-city child. Phi Delta Kappan, 63, 527-530.

Brophy, J. (1990). Teaching social studies for understanding and higher-order applications. The Elementary School Journal, 90(4), 367-417. https://doi.org/10.1086/461623

Brophy, J., \& Good, T. (1986). Teacher behavior and student achievement. In M. Wittrock (Ed.), Handbook of research on teaching. New York, NY: MacMillan.

Brophy, J., \& Good, T. (2008). Looking in classrooms. Boston, MA: Pearson Education.

Carnine, D. (2000). Why education experts resist effective practices. Thomas B. Fordham Foundation. https://doi.org/10.1353/pep.2000.0007

Chall, J. (2000). The academic achievement challenge: What really works in the classroom?. New York, NY: Guilford Press.

Clark, R., Kirschner, P., \& Sweller, J. (2006). Why minimal guidance during instruction does not work: An analysis of the failure of constructivist, discovery, problem-based, experiential, and inquiry-based teaching. Educational Psychologist, 41(2), 75-86. https://doi.org/10.1207/s15326985ep4102_1

Clark, R., Kirschner, P., \& Sweller, J. (2012, Spring). Putting students on the path to learning: The case for fully guided instruction. American Educator, 6-11.

Coleman, J. (1966). Equality of educational opportunity. National Center for Educational Statistics. 
Daniels, H., Hyde, A., \& Zemelman, S. (2005). Best practice: Today's standards for teaching and learning in American schools. Portsmouth, NH: Heinemann.

Delpit, L. (1986). Skills and other dilemmas of a progressive black educator. Harvard Educational Review, 56(4), 379-385. https://doi.org/10.17763/haer.56.4.674v5h1m125h3014

Ellis, A., \& Fouts, J. (1993). Research on educational innovations. Princeton Junction, NJ: Eye on Education.

Ellis, E., \& Worthington, L. (1994). Research synthesis on effective teaching principles and thedesign of quality tools for educators. Eugene, OR: National Center to Improve the Tools of Educators.

Farkas, S., \& Duffett, A. (2010). Cracks in the ivory tower? The views of education professors circa 2010. Thomas B. Fordham Foundation.

Gage, N. (1978). The scientific basis of the art of teaching. New York, NY: Teachers College Press.

Gay, G. (2002). Preparing for culturally responsive teaching. Journal of Teacher Education, 53(2), 106-116. https://doi.org/10.1177/0022487102053002003

Hirsch, E. D. (1996). The schools we need and why we don't have them. New York, NY: Doubleday. https://doi.org/10.2307/358685

Kim, T., \& Axelrod, S. (2005). Direct instruction: An educators' guide and a plea for action. The Behavior Analyst Today, 6(2), 111-120. https://doi.org/10.1037/h0100061

Kozloff, M., La Nunziata, L., Cowardin, J., \& Bessellieu, F. (2001). Direct instruction: Its contributions to high school achievement. The High School Journal, 84(2), 54-71.

Krahenbuhl, K. (2016). Student-centered education and constructivism: Challenges, concerns, and clarity for teachers. Clearing House, 89(3), 97-105. https://doi.org/10.1080/00098655.2016.1191311

Muijs, D., et al.. (2014). State of the art -- teacher effectiveness and professional learning. School Effectiveness and School Improvement, 25(2), 231-256. https://doi.org/10.1080/09243453.2014.885451

NCES. (2009). Achievement gaps: How black and white students in public schools perform in mathematics and reading on the National Assessment of Educational Progress. United States Department of Education. Retrieved from https://nces.ed.gov/nationsreportcard/pdf/studies/2009455.pdf

NCES. (2015). School composition and the black-white achievement gap. United States Department of Education. Retrieved from https://nces.ed.gov/nationsreportcard/subject/studies/pdf/school_composition_and_the_bw_achievement_ga p_2015.pdf

O'Neill, G. (1988). Teaching effectiveness: A review of the research. Canadian Journal of Education, 13(1), 162-185. https://doi.org/10.2307/1495174

Patrick, B., Hisley, J., \& Kempler, T. (2000). "What's everybody so excited about?": The effects of teacher enthusiasm on student intrinsic motivation and vitality. Journal of Experimental Education, 68. https://doi.org/10.1080/00220970009600093

Richards, H., Brown, A., \& Forde, T. (2007). Addressing diversity in schools: Culturally responsive pedagogy. Teaching Exceptional Children, 39(3), 64-68. https://doi.org/10.1177/004005990703900310

Rosenshine, B. (1970). Enthusiastic teaching: A research review. The School Review, 78(4), 499-514. https://doi.org/10.1086/442929

Rosenshine, B. (2002). Converging findings on classroom instruction. In A. Molnar (Ed.), School reform proposals: The research evidence. National Education Policy Center.

Rosenshine, B., \& Stevens, R. (1986). Teaching functions. In M. Wittrock (Ed.), Handbook of research on teaching. New York, NY: MacMillan.

Stevens, R., \& Rosenshine, B. (1981). Advances in research on teaching. Exceptional Education Quarterly, 2(1), 1-9. https://doi.org/10.1177/074193258100200106

Stone, J. E. (1996). Developmentalism: An obscure but pervasive restriction on educational improvement. Education Policy Analysis Archives, 4(8). https://doi.org/10.14507/epaa.v4n8.1996

Stone, J. E. (2002). Teacher training and pedagogical methods. In L. Izumi, \& W. Evers (Eds.), Teacher quality (pp. 33-54). Hoover Institution Press.

Sum, A., Khatiwada, I., \& McLaughlin, J. (2009). The consequences of dropping out of high school: Joblessness 
and jailing for high school dropouts and the high cost for taxpayers. Boston, Massachusetts: Center for Labor Market Studies.

Sweller, J., Van Merrienboer, J., \& Paas, F. (1998). Cognitive architecture and instructional design. Educational Psychology Review, 10(3), 251-296. https://doi.org/10.1023/A:1022193728205

Willingham, D. (2009). Why don't students like school? A cognitive scientist answers questions about how the mind works and what it means for the classroom. San Francisco, CA: Jossey-Bass. https://doi.org/10.1002/9781118269527

\section{Copyrights}

Copyright for this article is retained by the author(s), with first publication rights granted to the journal.

This is an open-access article distributed under the terms and conditions of the Creative Commons Attribution license (http://creativecommons.org/licenses/by/4.0/). 